\section{Wear Tolerance, Growth, and Quality of Seashore Paspalum in Response to Nitrogen and Potassium}

\author{
L.E. Trenholm ${ }^{1}$ \\ Department of Environmental Horticulture, University of Florida, P.O. Box \\ 110670, Gainesville, FL 32611-0670
}

R.N. Carrow ${ }^{2}$ and R.R. Duncan ${ }^{2}$

Crop and Soil Sciences Department, Georgia Experiment Station, University of Georgia, Griffin, GA 30223-1797

Additional index words. Paspalum vaginatum, turfgrass, fertility, traffic, nutrition

\begin{abstract}
Damage from traffic can seriously injure athletic field turfgrass, although fertility regimes can influence wear tolerance. While excess nitrogen $(\mathrm{N})$ can reduce wear tolerance, moderate $\mathbf{N}$ has improved tolerance and hastened recovery from injury. Potassium (K) may enhance wear tolerance through regulation of turgor potential. This research was undertaken to determine shoot growth and wear tolerance of seashore paspalum (Paspalum vaginatum Swartz) to $\mathbf{N}$ and $\mathrm{K}$ application. Field studies were conducted in 1998 at the Univ. of Georgia Experiment Station, Griffin. Grasses were established on U.S. Golf Association specification greens in 1996. Fertility treatments were applied at annual $\mathrm{N}$ rates of 196 and $392 \mathrm{~kg} \cdot \mathrm{ha}^{-1}$ and $\mathrm{K}$ rates of 92 and $392 \mathrm{~kg} \cdot \mathrm{ha}^{-1}$. The higher $N$ rate increased wear tolerance, shoot growth, shoot density, visual quality, and color of the two ecotypes, AP 10 and AP 14, but reduced their visible range spectral reflectance, indicating greater absorption of photosynthetically active radiation $(P A R)$. Measured responses to $\mathrm{K}$ were minimal and no enhancement of wear tolerance in response to $K$ treatment was noted.
\end{abstract}

Traffic can impose two distinct forms of injury on turf. Wear injury to shoot tissue is manifested by abrasion or tearing of leaf tissue, resulting in chlorophyll degradation and reduced photosynthesis. The second type of traffic damage, soil compaction, is initially expressed in the root zone. The overall effects of either injury is inhibition of turf growth, loss of shoot density, and premature senescence of shoot or root tissue. Rates of recovery vary based on inherent growth rate and degree of severity of the injury.

The two elements required in greatest quantity for turfgrass growth and quality are $\mathrm{N}$ and $\mathrm{K}$, and can also influence turfgrass tolerance to environmental stresses. While enhanced shoot growth following $\mathrm{N}$ applications can reduce tolerance to wear injury (Beard, 1973), moderate $\mathrm{N}$ fertility can increase wear tolerance in cool-season grasses (Carroll and Petrovic, 1991; Shearman and Beard, 1975).

Received for publication 14 Mar. 2000. Accepted for publication 14 Aug. 2000. We gratefully acknowledge support from the U.S. Golf Association, the Golf Course Superintendents Association of America, the Georgia Turfgrass Foundation Trust, Turfgrass Producers International, and the Potash and Phosphate Institute. The cost of publishing this paper was defrayed in part by the payment of page charges. Under postal regulations, this paper therefore must be hereby marked advertisement solely to indicate this fact.

${ }^{1}$ Assistant Professor. E-mail address: Ltrenholm@ mail.ifas.ufl.edu

${ }^{2}$ Professor. undertaken to: 1) provide guidelines for judicious use of $\mathrm{N}$ and $\mathrm{K}$ on seashore paspalum; and 2) evaluate the influence of $\mathrm{N}$ and $\mathrm{K}$ on wear tolerance of this species.

\section{Materials and Methods}

This research was conducted at the Univ. of Georgia Experiment Station in Griffin, and was repeated twice during the 1998 growing season with very similar results. Only results of the first trial are presented here.

Two seashore paspalum ecotypes, AP 10 and AP 14 (selections from Alden Pines Golf Club, Ft. Myers, Fla.), were established on U.S. Golf Association (USGA)-specification, sand-based greens in Summer 1996. Plots were mowed three times weekly with a greens reel mower at $4 \mathrm{~mm}$ and clippings were removed. Plots were verticut and topdressed at the start of the growing season. Topdressing material was identical to the sand-based mix in which the grasses were growing. Irrigation was provided as needed throughout the test period to prevent wilting.

Evaluations included turf quality, turf density, and percentage of shoot tissue injury. Visual quality ratings were based on color, shoot density, and uniformity of stand, where $1=$ no live grass and $9=$ dark-green, dense, uniform grass. Turf density ratings were based only on shoot density, where $1=$ no grass and $9=$ uniform dense grass. Shoot tissue injury (STI), which was taken on wear-treated plots only, was defined as the percentage of leaves visually seen as injured (chlorotic) or killed (necrotic) because of wear. Wear tolerance was defined as 100-STI.

Treatments were arranged in a factorial combination of two $\mathrm{N}$ and two $\mathrm{K}$ rates with four replications and were applied every 10 to $12 \mathrm{~d}$. Nitrogen was applied as ammonium nitrate at 19.6 or $39.2 \mathrm{~kg} \cdot \mathrm{ha}^{-1}$ for 10 applications, for total annual rates of either 196 or 392 $\mathrm{kg} \cdot \mathrm{ha}^{-1}$. Potassium was applied as potassium chloride at 9.2 or $39.2 \mathrm{~kg} \cdot \mathrm{ha}^{-1}$ for annual rates of either 92 or $392 \mathrm{~kg} \cdot \mathrm{ha}^{-1}$. A single wear treatment, sufficient to cause adequate shoot tissue injury for data collection, was applied on 25 June. The wear treatment was applied in a strip within replications as 74 multiple passes at one time. A differential slip wear device with rubber-covered rollers was used for applying wear at $0.90 \mathrm{~kg} \cdot \mathrm{cm}^{-1}$ of force. The differential slip arrangement allowed the rollers to turn at different speeds so that abrasion and scuffing actions were created.

A greens reel mower set at a mowing height of $4 \mathrm{~mm}$ was used to collect shoot growth clippings from a $0.5-\mathrm{m}^{2}$ area from the center of the plots. Shoot tissue was analyzed for percentage of cell wall components (total cell wall, cellulose, hemicellulose, lignocellulose, and lignin) following the methodology of Goering and Van Soest (1970). Quantity of verdure tissue was measured by pulling three 5.7-cm-diameter cores per plot following mowing. All tissue was removed from cores with shears, collectively dried in a forced air drier at $70^{\circ} \mathrm{C}$, and weighed. Counts were taken on number of shoots per core. 
Table 1. Average quality, color, density, and shoot tissue injury scores (STI) of two seashore paspalum ecotypes as influenced by N and K at 7 and $14 \mathrm{~d}$ after wear treatment (DAWT).

\begin{tabular}{|c|c|c|c|c|c|c|c|c|c|c|c|c|c|c|c|c|}
\hline \multirow[b]{4}{*}{ Ecotype } & \multirow{4}{*}{$\begin{array}{c}\mathrm{N} \\
--\mathrm{kg} \cdot \mathrm{ha}\end{array}$} & \multirow{4}{*}{$\begin{array}{l}\mathrm{K} \\
a^{-1}--\end{array}$} & \multicolumn{7}{|c|}{7 DAWT } & \multicolumn{7}{|c|}{14 DAWT } \\
\hline & & & \multicolumn{2}{|c|}{ Quality } & \multicolumn{2}{|c|}{ Color } & \multicolumn{2}{|c|}{ Density } & \multirow{3}{*}{$\frac{\text { STI }(\%)}{\text { Wear }}$} & \multicolumn{2}{|c|}{ Quality } & \multicolumn{2}{|c|}{ Color } & \multicolumn{2}{|c|}{ Density } & \multirow{3}{*}{$\begin{array}{r}\text { STI }(\%) \\
\text { Wear }\end{array}$} \\
\hline & & & & No & & $\mathrm{No}$ & & No & & & $\mathrm{No}$ & & $\mathrm{No}$ & & No & \\
\hline & & & Wear & Wear & Wear & Wear & Wear & Wear & & Wear & Wear & Wear & Wear & Wear & Wear & \\
\hline \multirow[t]{5}{*}{ AP-10 } & 196 & 92 & 6.7 & 7.4 & 7.1 & 7.7 & 7.4 & 7.9 & 5.0 & 7.3 & 7.4 & 7.4 & 7.6 & 7.5 & 7.9 & 2.8 \\
\hline & & 392 & 6.5 & 7.5 & 7.2 & 7.8 & 7.3 & 7.9 & 7.5 & 7.2 & 7.4 & 7.5 & 7.7 & 7.6 & 7.9 & 2.0 \\
\hline & 392 & 92 & 7.6 & 8.1 & 8.1 & 8.5 & 8.0 & 8.6 & 2.5 & 8.1 & 8.2 & 8.3 & 8.7 & 8.4 & 8.7 & 0 \\
\hline & & 392 & 7.8 & 7.9 & 8.2 & 8.3 & 8.1 & 8.4 & 2.5 & 8.1 & 8.3 & 8.4 & 8.7 & 8.5 & 8.8 & 0.8 \\
\hline & $\mathrm{CV}(\%)$ & & 6 & 2 & 4 & 2 & 4 & 2 & 63 & 7 & 3 & 8 & 3 & 7 & 4 & 109 \\
\hline \multirow[t]{6}{*}{ AP-14 } & 196 & 92 & 4.8 & 6.3 & 5.3 & 6.5 & 5.3 & 6.7 & 23.8 & 5.0 & 6.0 & 5.4 & 6.2 & 5.6 & 6.4 & 7.5 \\
\hline & & 392 & 5.1 & 6.1 & 5.6 & 6.3 & 5.7 & 6.7 & 15.0 & 5.3 & 6.1 & 5.5 & 6.1 & 5.7 & 6.5 & 8.8 \\
\hline & 392 & 92 & 6.9 & 7.7 & 7.3 & 8.0 & 7.1 & 8.1 & 2.5 & 7.3 & 7.7 & 7.6 & 8.0 & 7.6 & 8.1 & 0 \\
\hline & & 392 & 6.9 & 7.5 & 7.5 & 7.9 & 7.2 & 8.0 & 5.0 & 7.2 & 7.6 & 7.4 & 7.8 & 7.8 & 8.0 & 0 \\
\hline & $\mathrm{CV}(\%)$ & & 9 & 5 & 8 & 4 & 8 & 6 & 65 & 8 & 6 & 8 & 5 & 7 & 5 & 99 \\
\hline & & & & & & & & $P$ & & & & & & & & \\
\hline \multirow[t]{3}{*}{ AP-10 } & $\mathrm{N}$ & & 0.001 & 0.001 & 0.001 & 0.001 & 0.001 & 0.001 & 0.02 & 0.01 & 0.001 & 0.04 & 0.001 & 0.01 & 0.001 & 0.03 \\
\hline & $\mathrm{K}$ & & NS & NS & NS & NS & NS & NS & NS & NS & NS & NS & NS & NS & NS & NS \\
\hline & $N^{*} \mathrm{~K}$ & & NS & NS & NS & 0.10 & NS & NS & NS & NS & NS & NS & NS & NS & NS & NS \\
\hline \multirow[t]{3}{*}{ AP-14 } & $\mathrm{N}$ & & 0.001 & 0.001 & 0.001 & 0.001 & 0.001 & 0.001 & 0.02 & 0.001 & 0.001 & 0.001 & 0.001 & 0.001 & 0.001 & 0.02 \\
\hline & $\mathrm{K}$ & & NS & NS & NS & NS & NS & NS & NS & NS & NS & NS & NS & NS & NS & NS \\
\hline & $\mathrm{N}^{*} \mathrm{~K}$ & & NS & NS & NS & NS & NS & NS & NS & NS & NS & NS & NS & NS & NS & NS \\
\hline
\end{tabular}

Ns Nonsignificant at $P>0.10$.

Reflectance measurements were taken with a hand-held Cropscan multispectral model MSR16 radiometer (Cropscan, Rochester, Minn.) fitted with filters to measure reflectance at 507, 559, 661, 706, 760, 813, and 935 $\mathrm{nm}$. In addition, the following growth and stress indices were evaluated: 1) NDVI (normalized difference vegetation index) growth index computed as $\left[\mathrm{R}_{935}-\mathrm{R}_{661}\left(/\left(\mathrm{R}_{935}+\right.\right.\right.$ $R_{661}$ )]; 2) IR/R (leaf area index) growth index computed as $\mathrm{R}_{935} / \mathrm{R}_{661} ; 3$ ) Stress 1 index computed as $\mathrm{R}_{706} / \mathrm{R}_{760}$; and 4) Stress 2 index computed as $\mathbf{R}_{706 /} \mathbf{R}_{813}$.

The radiometer was held at a height of $2 \mathrm{~m}$ and measured a plot area of $\approx 1 \mathrm{~m}^{2}$. Reflectance readings were taken within a time period from 1100 to 1300 HR under conditions of minimal cloud cover.

Both of the greens ecotypes evaluated in this project were established in separate blocks; therefore, data for each were analyzed separately, using a randomized complete-block design with four replications. The wear treatment represented a strip plot within each replication of each test. General linear model analysis (SAS Institute, 1987) was used to determine significant $(P<0.05)$ differences due to fertility and wear treatments.

\section{Results and Discussion}

Nitrogen had a highly significant influence on visual turf quality scores of both ecotypes under both wear and nonwear conditions (Table 1). Application of $\mathrm{N}$ at $392 \mathrm{~kg} \cdot \mathrm{ha}^{-1}$ increased turf quality, color, and density more than did N at $196 \mathrm{~kg} \cdot \mathrm{ha}^{-1}$, regardless of $\mathrm{K}$ rate. Turf color and density of both grasses at 7 and 14 days after wear treatment (DAWT) were also enhanced by the higher $\mathrm{N}$ rate.

In contrast with data of Beard, (1973), who stated that higher $\mathrm{N}$ decreased wear tolerance due to reduced thickness of cell walls and greater succulence of shoot tissue, we found that STI was reduced by the higher $\mathrm{N}$ rate at both 7 and 14 DAWT. Similarly, Carroll and
Petrovic (1991) and Shearman and Beard (1975) reported better wear tolerance in response to moderate $\mathrm{N}$ fertility in creeping bentgrass. Moderate $\mathrm{N}$ should produce these results, since it would yield more shoot tissue to absorb the injury, and faster regrowth of turf following wear injury.

Shoot density and verdure of both ecotypes also increased with $\mathrm{N}$ (Table 2). As with the visual ratings, no shoot responses to $\mathrm{K}$ were evident.

Cell wall components differed in response to fertility treatments only in AP-14 (Table 3), where high $\mathrm{N}$ reduced leaf total cell wall
(TCW), lignocellulose, and cellulose, and increased hemicellulose contents. Greater shoot growth resulting from the higher $\mathrm{N}$ rate produced thinner cell walls, resulting in lower TCW. In some cases, TCW and wear tolerance were negatively correlated ( $r=-0.53$ for AP 10 and $r=-0.81$ for AP 14 ). This was consistent with the results of Trenholm et al. (2000a), who reported that lower leaf TCW was associated with greater wear tolerance in this species. This response was attributed to greater cell elasticity under lower TCW content. Beard (1973) reported that thinner cell walls in response to $\mathrm{N}$ fertilization could reduce wear

Table 2. Effects of $\mathrm{N}$ and $\mathrm{K}$ application on shoot growth, density, and verdure of 2 seashore paspalum ecotypes. ${ }^{z}$

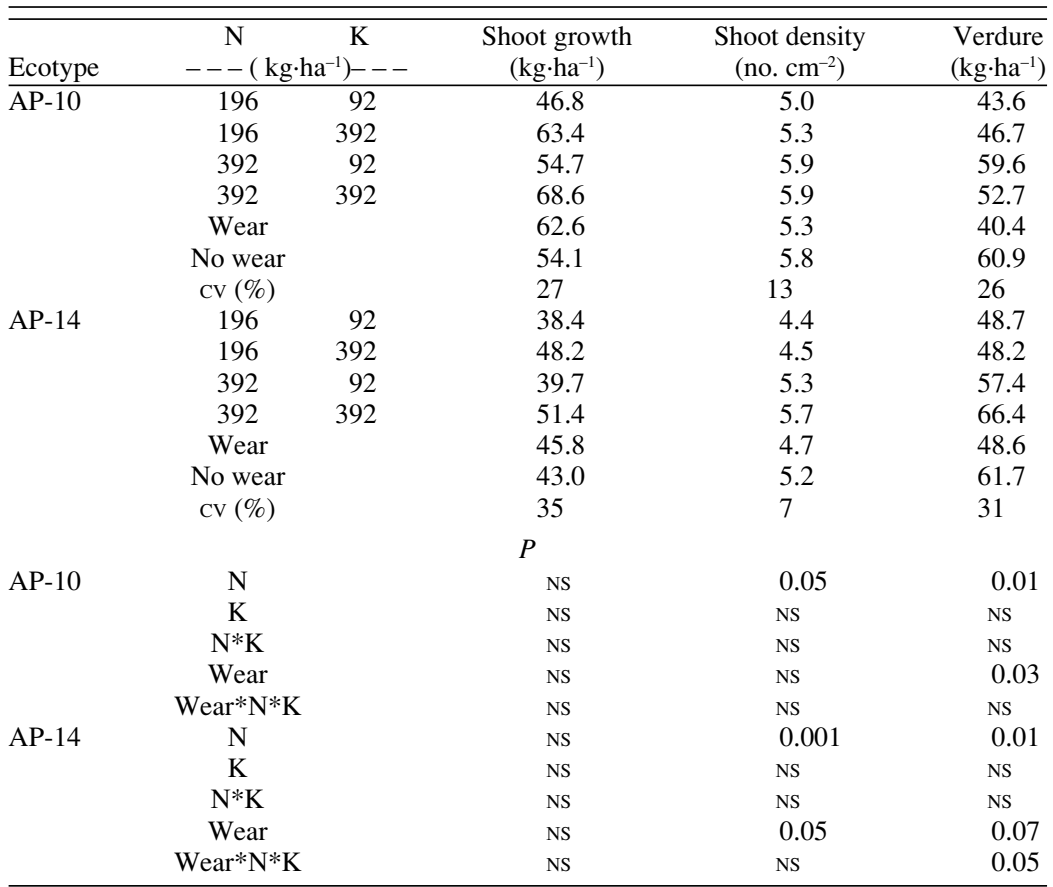

${ }^{2}$ Shoot growth taken at 6 DAWT. Shoot density and verdure measured at 6 and 9 DAWT.

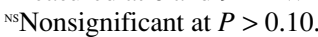


tolerance, and Trenholm et al. (2000a) found that greater TCW reduced wear tolerance in coarse-leaved paspalum ecotypes, with no difstudy.

Spectral reflectance values varied primarily due to $\mathrm{N}$ rate and wear (Table 4 ). These values are indicative of the quantity of $P A R$ absorbed by plant tissue for photochemical processes; in a turf canopy, the amount of light not reflected is generally that absorbed by the plant. Throughout the visible range wavelengths $\left(\mathrm{R}_{507}, \mathrm{R}_{559}, \mathrm{R}_{661}\right.$, and $\left.\mathrm{R}_{706}\right)$, reflectance was significantly lower at the higher $\mathrm{N}$ rate, ferences in wear tolerance among the fineleaved ecotypes such as those evaluated in this

indicating greater absorption of $\mathrm{PAR}$ at higher $\mathrm{N}$ rates. Trenholm et al. (2000b) found that reflectance values in these wavelengths were inversely correlated with $\mathrm{N}$ rate in creeping bentgrass (Trenholm et al., 2000b). Growth (NDVI and IR/R) and stress (Stress1 and Stress2) ratios were also highly responsive to $\mathrm{N}$ rate. Higher values of growth ratios, indicating greater growth, and reduced stress values likewise support previous spectral research (Trenholm et al., 1999, 2000b).

Reflectance at 661 and $813 \mathrm{~nm}$ and the growth and stress ratios have reliably distinguished between wear-treated and nontreated plots and have shown strong associations $\left(r^{2}=\right.$

Table 3. Cell wall analysis of two seashore paspalum ecotypes as influenced by $\mathrm{N}$ and $\mathrm{K}$.

\begin{tabular}{|c|c|c|c|c|c|c|c|}
\hline \multirow[b]{3}{*}{ Ecotype } & \multicolumn{2}{|c|}{ Treatments } & \multicolumn{5}{|c|}{ Cell wall concn } \\
\hline & $\mathrm{N}$ & K & TCW & Lignocellulose & Lignin & Hemicellulose & Cellulose \\
\hline & $---\mathrm{kg} \cdot \mathrm{ha}^{-}$ & $1---$ & ----1 & -------- & $\mathrm{g} \cdot \mathrm{kg}^{-1}-$ & ---------- & ----- \\
\hline \multirow[t]{5}{*}{ AP-10 } & 196 & 92 & 716.2 & 362.8 & 53.1 & 353.4 & 309.7 \\
\hline & 196 & 392 & 688.5 & 319.3 & 64.4 & 369.2 & 254.9 \\
\hline & 392 & 92 & 706.0 & 351.2 & 55.8 & 354.8 & 295.4 \\
\hline & 392 & 392 & 699.0 & 344.8 & 55.5 & 354.2 & 289.3 \\
\hline & $\mathrm{CV}(\%)$ & & 6 & 26 & 16 & 13 & 34 \\
\hline \multirow[t]{6}{*}{ AP-14 } & 196 & 92 & 709.9 & 391.2 & 61.2 & 318.7 & 330.1 \\
\hline & 196 & 392 & 670.3 & 328.9 & 55.9 & 341.4 & 273.0 \\
\hline & 392 & 92 & 639.3 & 252.1 & 67.6 & 387.2 & 184.5 \\
\hline & 392 & 392 & 642.7 & 287.0 & 64.5 & 355.7 & 222.5 \\
\hline & $\mathrm{CV}(\%)$ & & 3 & 14 & 17 & 8 & 19 \\
\hline & & & & $P$ & & & \\
\hline \multirow[t]{3}{*}{ AP-10 } & $\mathrm{N}$ & & NS & NS & NS & NS & NS \\
\hline & $\mathrm{K}$ & & NS & NS & NS & NS & NS \\
\hline & $N^{*} \mathrm{~K}$ & & NS & NS & NS & NS & NS \\
\hline \multirow[t]{3}{*}{ AP-14 } & $\mathrm{N}$ & & 0.001 & 0.01 & NS & 0.01 & 0.01 \\
\hline & K & & NS & NS & NS & NS & NS \\
\hline & $\mathrm{N}^{*} \mathrm{~K}$ & & 0.08 & 0.04 & NS & 0.06 & 0.06 \\
\hline
\end{tabular}

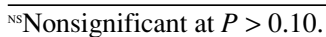

0.76) with turf visual quality and density scores (Trenholm et al., 1999). Reflectance is reduced on stressed plots because of tissue senescence, loss of leaf area, or chlorophyll degradation (Carter, 1994; Carter and Miller, 1994). As in previous research, significant increases were observed in reflectance at 661 and $813 \mathrm{~nm}$ because of senescence and damage to shoot tissue caused by wear. The increase in reflectance suggests reduced photosynthetic capacity resulting from the injury.

Responses to $\mathrm{K}$ were minimal for all variables. No response of turf quality, density, color, or STI to K application was noted on wear-treated plots (Tables 1 and 2). Reports in the literature are inconsistent with regard to effects of K on wear tolerance. Similar to our results, Kentucky bluegrass and creeping bentgrass exhibited neither greater wear tolerance nor recovery from wear in response to $\mathrm{K}$ (Carroll and Petrovic, 1991; Hawes and Decker, 1977). Likewise, recovery of bermudagrass from coring and verticutting was not enhanced by K (Carrow et al., 1987). In contrast, applied $\mathrm{K}$ increased wear tolerance in seashore paspalum on a clay soil (Trenholm et al., 2001). Higher K leaf concentration has also been identified as an important nutrient mechanism involved in enhancing wear tolerance of both seashore paspalum and bermudagrass (Trenholm et al., 2000a). Potassium has been cited as enhancing wear tolerance because of greater turgidity and reduced tissue succulence (Beard, 1973), as well as effects on stomatal control and cell turgidity (Carrow, 1995).

The $\mathrm{K}$ amendments did not affect reflectance values in AP 10; AP 14 had slightly higher reflectance values $(P=0.07$ and 0.09$)$ at 559 and $706 \mathrm{~nm}$, respectively, in both stud-

Table 4. Spectral reflectance values of two seashore paspalum cultivars as influenced by N and K at 7 DAWT. Measurements taken with a Cropscan model MSR16 radiometer.

\begin{tabular}{|c|c|c|c|c|c|c|c|c|c|c|c|c|c|}
\hline \multirow{2}{*}{ Ecotype } & \multirow{2}{*}{$\begin{array}{c}\mathrm{N} \\
---\mathrm{kg} \cdot \mathrm{ha}^{-1}\end{array}$} & \multirow{2}{*}{$\begin{array}{c}\mathrm{K} \\
---\end{array}$} & \multicolumn{11}{|c|}{ Wavelength (nm) } \\
\hline & & & 507 & 559 & 661 & 706 & 760 & 813 & 935 & $\mathrm{NDVI}^{\mathrm{z}}$ & $\mathrm{IR} / \mathrm{R}$ & Stress1 & Stress2 \\
\hline \multirow[t]{7}{*}{$\overline{\mathrm{AP}} 10$} & 196 & 92 & 5.3 & 9.6 & 5.3 & 15.0 & 57.2 & 49.8 & 55.7 & 0.82 & 10.6 & 0.26 & 0.30 \\
\hline & 196 & 392 & 5.3 & 9.6 & 5.2 & 15.1 & 58.1 & 50.2 & 56.1 & 0.83 & 10.8 & 0.26 & 0.30 \\
\hline & 392 & 92 & 5.0 & 8.8 & 4.8 & 13.9 & 57.9 & 50.1 & 55.8 & 0.84 & 12.0 & 0.24 & 0.28 \\
\hline & 392 & 392 & 5.0 & 8.9 & 4.7 & 14.0 & 59.4 & 51.4 & 57.1 & 0.85 & 12.3 & 0.24 & 0.28 \\
\hline & Wear & & 5.2 & 9.2 & 5.5 & 14.5 & 52.2 & 45.1 & 51.4 & 0.81 & 9.5 & 0.28 & 0.32 \\
\hline & No wear & & 5.1 & 9.3 & 4.6 & 14.5 & 64.1 & 55.7 & 61.0 & 0.86 & 13.4 & 0.23 & 0.26 \\
\hline & $\mathrm{CV}(\%)$ & & 2 & 2 & 3 & 2 & 2 & 4 & 4 & 1 & 5 & 3 & 5 \\
\hline \multirow[t]{7}{*}{ AP 14} & 196 & 92 & 6.0 & 10.4 & 6.7 & 16.2 & 46.8 & 44.9 & 51.8 & 0.77 & 7.9 & 0.35 & 0.37 \\
\hline & 196 & 392 & 6.0 & 10.5 & 6.8 & 16.4 & 47.9 & 45.8 & 53.1 & 0.77 & 8.1 & 0.35 & 0.36 \\
\hline & 392 & 92 & 5.4 & 9.4 & 5.7 & 14.8 & 47.8 & 45.8 & 53.3 & 0.80 & 9.6 & 0.32 & 0.33 \\
\hline & 392 & 392 & 5.5 & 9.6 & 5.7 & 15.0 & 48.2 & 46.5 & 53.8 & 0.81 & 9.7 & 0.31 & 0.33 \\
\hline & Wear & & 5.8 & 9.8 & 6.9 & 15.6 & 42.6 & 40.6 & 48.2 & 0.75 & 7.0 & 0.37 & 0.39 \\
\hline & No wear & & 5.6 & 10.1 & 5.5 & 15.6 & 52.7 & 50.9 & 57.7 & 0.83 & 10.6 & 0.30 & 0.31 \\
\hline & $\mathrm{CV}(\%)$ & & 3 & 3 & 5 & 3 & 3 & 3 & 2 & 2 & 6 & 3 & 4 \\
\hline \multicolumn{14}{|l|}{$\mathrm{P}$} \\
\hline \multirow[t]{5}{*}{ AP 10} & $\mathrm{~N}$ & & 0.001 & 0.001 & 0.001 & 0.001 & NS & NS & NS & 0.01 & 0.01 & 0.01 & 0.01 \\
\hline & $\mathrm{K}$ & & NS & NS & NS & NS & NS & NS & NS & NS & NS & NS & NS \\
\hline & $\mathrm{N}^{*} \mathrm{~K}$ & & NS & NS & NS & NS & NS & NS & NS & NS & NS & NS & NS \\
\hline & Wear & & NS & NS & 0.01 & NS & 0.001 & 0.001 & 0.001 & 0.001 & 0.001 & 0.001 & 0.001 \\
\hline & Wear*N*K & & NS & NS & NS & NS & NS & NS & NS & NS & NS & NS & NS \\
\hline \multirow[t]{5}{*}{ AP 14} & $\mathrm{~N}$ & & 0.001 & 0.001 & 0.001 & 0.001 & NS & NS & NS & 0.001 & 0.001 & 0.001 & 0.001 \\
\hline & K & & NS & 0.07 & NS & 0.09 & NS & NS & NS & NS & NS & NS & NS \\
\hline & $\mathrm{N}^{*} \mathrm{~K}$ & & NS & NS & NS & NS & NS & NS & NS & NS & NS & NS & NS \\
\hline & Wear & & NS & NS & 0.001 & NS & 0.001 & 0.001 & 0.001 & 0.001 & 0.001 & 0.001 & 0.001 \\
\hline & Wear*N*K & & NS & NS & NS & NS & NS & NS & NS & NS & NS & NS & NS \\
\hline
\end{tabular}

${ }^{\mathrm{z} N D V I}, \mathrm{IR} / \mathrm{R}$ : highest values $=$ best. Stress1 and Stress2: lowest values $=$ best.

Nonsignificant at $P>0.10$. 
ies. We found no previous reports of an effect of $\mathrm{K}$ on spectral reflectance in the literature.

Both ecotypes in this study were strongly influenced by $\mathrm{N}$, with greater shoot growth, shoot density, visual turf quality, color, and density following application of $\mathrm{N}$ at 392 $\mathrm{kg} \cdot \mathrm{ha}^{-1}$ than at the lower rate. Shoot tissue injury resulting from wear was significantly reduced at the higher rate. Cell wall components that may influence wear tolerance exhibited inconsistent responses to fertility treatments, but when differences did occur, the higher rate of $\mathrm{N}$ reduced leaf TCW, lignocellulose, and cellulose, and increased hemicellulose contents.

Wear tolerance increases with reduced leaf TCW content (Trenholm et al., 2000a), and the current results support the observation that higher $\mathrm{N}$ rates reduce wear injury through this mechanism.

\section{Literature Cited}

Beard, J.B. 1973. Turfgrass: Science and Culture. Prentice Hall, New York.

Beard, J.B., S.I. Sifers, and G.W. Menn. 1991. Cultural strategies for seashore paspalum. Grounds Maintenance. August p. 32, 62.
Canaway, P.M.. 1984. The response of Lolium perenne turf grown on sand and soil to fertilizer nitrogen. I. Ground cover response as affected by football-type wear. J. Sports Turf Res. Inst. 60:8-18.

Carroll, M.J. and A.M. Petrovic. 1991. Wear tolerance of Kentucky bluegrass and creeping bentgrass following nitrogen and potassium application. HortScience 26:851-853.

Carrow, R.N., B.J. Johnson, and R.E. Burns. 1987. Thatch and quality of Tifway bermudagrass in relation to fertility and cultivation. Agron. J. 79:524-530.

Carter, G.A. 1994. Ratios of reflectances in narrow wavebands as indicators of plant stress. Intl. J. Remote Sensing 15:697-703.

Carter, G.A. and R.L. Miller. 1994. Early detection of plant stress by digital imaging within narrow stress-sensitive wavebands. Remote Sens. Environ. 50:295-302.

Dudeck, A.E. and C.H. Peacock. 1985. Effects of salinity on seashore paspalum turfgrasses. Agron. J. 77:47-50.

Goering, H.K. and P.J. Van Soest. 1970. Forage fiber analysis (apparatus, reagents, procedures, and some applications). U.S. Dept. of Agr. Hdbk. 379. U.S. Gov. Print. Office, Washington, D.C.

Harivandi, M.A., W. Davis, V.A. Gibeault, M.Henry, J. VanDam, and L. Wu. 1984. Selecting the best turfgrass. Calif. Turfgrass Cult. 34:17-18.

Hawes, D.T. and A.M. Decker. 1977. Healing potential of creeping bentgrass as affected by nitrogen and soil temperature. Agron. J. 69:212214.

Malcolm, C.V. 1969. Saltland pastures. J. Agr. Western Australia 10:119-122.

Marcum, K.B. and C.L. Murdoch. 1990. Growth responses, ion relations, and osmotic adaptations of eleven $\mathrm{C}_{4}$ grasses to salinity. Agron. J. 82:892-896.

Marcum, K.B. and C.L. Murdoch. 1994. Salinity tolerance mechanisms of six $\mathrm{C}_{4}$ turfgrasses. J. Amer. Soc. Hort. Sci. 119:779-784.

SAS Institute. 1987. SAS user's guide: Statistics. 6th ed. SAS Inst., Cary, N.C.

Shearman, R.C. and J.B. Beard. 1975. Influence of nitrogen and potassium on turfgrass wear tolerance. Agron. Abstr. p. 101.

Trenholm, L.E., R.N. Carrow, and R.R. Duncan. 1999. Relationship of multispectral radiometry data to qualitative data in turfgrass research. Crop Sci. 39:763-769.

Trenholm, L.E., R.N. Carrow, and R.R. Duncan. 2000a. Mechanisms of wear tolerance in seashore paspalum and bermudagrass. Crop Sci. 40:1350-1357.

Trenholm, L.E., M.J. Schlossberg, G. Lee, S.A. Geer, and W. Parks. 2000b. An evaluation of multispectral responses on selected turfgrass species. Intl. J. Remote Sensing. 21:709-721.

Trenholm, L.E., R.R. Duncan, R.N. Carrow, and G.H. Snyder. 2001. The influence of silica on growth, quality, and wear tolerance of seashore paspalum. J. Plant Nutr. 24:1-15. 